\title{
Johannesbaptistia floridana sp. nov. (Chroococcales, Cyanobacteria), a novel marine cyanobacterium from coastal South Florida (USA)
}

\author{
David E. BerTHOLD ${ }^{1}$, Forrest W. LeFLeR ${ }^{1}$, Vera R. WeRNER ${ }^{2} \&$ H. Dail LAUGHINGHOUSE IV ${ }^{1 *}$
}

\author{
${ }^{l}$ Agronomy Department, Fort Lauderdale Research and Education Center, University of Florida / IFAS, 3205 \\ College Avenue, Davie, FL 33314, USA; *Corresponding author e-mail: hlaughinghouse@ufl.edu, Tel: \\ +1-954-577-6382, ORCID\#: 0000-0003-1018-6948 \\ ${ }^{2}$ Museum of Natural Sciences, Secretary of the Environment and Infrastructure, Rua Dr. Salvador França 1427, \\ 90690-000, Porto Alegre, RS, Brazil
}

\begin{abstract}
Mat dwelling species of cyanobacteria are diverse and integral to coastal marine sediment systems. Though observed throughout the globe, much of this diversity remains undescribed, especially on South Florida coast where cyanobacteria are pronounced. To help elucidate this diversity, one species of cyanobacteria from the marine sediments of South Florida was studied. Typical morphological features including uniseriate pseudofilaments with facultative intercellular gaps and cell division in one plane, transversely to the longer cell axis, indicated that the species belonged to the genus Johannesbaptistia De Toni. The combination of 16S rRNA gene and 16S-23S rRNA internal transcriber spacer (ITS), along with the diagnosable morphological characteristics suggest uniqueness from previously described species, thus supports the erection of the novel species Johannesbaptistia floridana sp. nov.
\end{abstract}

Key words: benthic, Cyanothrichaceae, ecology, epipelic, morphology, new species, North America, subtropical, 16S rRNA, 16S-23S rRNA ITS

\section{INTRODUCTION}

Johannesbaptistia De Toni (synonym Cyanothrix Gardner, Heterohormogonium Copeland) is a cosmopolitan genus of cyanobacteria described from many regions throughout Europe, the Americas, Asia and the Caribbean (Copeland 1936; Marshall 1981; Wenzel \& HalPerin 1987; HINDÁK 1988; Golubić \& ABED 2010). The genus inhabits lakes, brackish or estuarine pools and rivers, and can be found entangled within cyanobacterial mats (RICHERT et al. 2006; KOMÁrEK \& KomÁRKOVÁ-LEGNEROVÁ 2007; ROSEN \& MAREŠ 2016) and epipelic on benthic coastal substrata (this study). Currently, only one species has been studied in depth: Johannesbaptistia pellucida (Dickie) Taylor et Drouet and a total of five species are accepted: Johannesbaptistia desikacharyi Gupta et Das, J. pellucida, J. primaria (Gardner) De Toni (type species), J. schizodichotoma (Copeland) Komárek et Anagnostidis, and J. whitfordii Thomas et Gonzalves (GUIRY \& GUIRY 2020). Several other species with similar characteristics to Johannesbaptistia have been described but remain synonymous (KomÁREK \& ANAGNOSTIDIS 1998) to the currently described species or unrevised.

Johannesbaptistia pellucida was originally described as Hormospora pellucida (DICKIE 1874). GARDNER (1927) designated this genus as Cyanothrix, while TAYLOR (1928) erroneously named it Nodularia (?) fusca. However, the assignment to Cyanothrix was improper, as it was already in use by SCHMIDLE (1897) to designate Cyanophyceae that belonged to the genus Hapalosiphon Nägeli. Consequently, DE ToNi (1934) proposed amending the genus Cyanothrix to Johannesbaptistia. In 1937, Taylor recognized the similarity between the originally ascribed Nodularia(?) fusca with Cyanothrix and informed Drouet, and in 1938, they established a new generic combination inclusive of all the of previous synonyms and species: $J$. primaria (the type species), J. pellucida, J. willei, and J. gardneri (Drouet 1938).

The genus Johannesbaptistia remains poorly understood systematically, as there is only one species $(J$. pellucida) that contains a short sequence of the 16S rRNA gene in GenBank (\# AJ621836). To fill this information gap and further uncover the diversity within this genus, we isolated and cultured a unique strain of Johannesbaptistia from the coast of South Florida and are proposing it as a new species to science: Johannesbaptistia floridana sp. nov. It has characteristics dissimilar to other currently described species of the genus, and we present data on 
the morphology, ecology, 16S rRNA gene and 16S-23S rRNA internal transcribed spacer (ITS).

\section{Materials ANd Methods}

Isolation and culture. Benthic sediment samples were collected from the South Florida coast ( $\left.25^{\circ} 27^{\prime} 53.01^{\prime \prime} \mathrm{N}, 80^{\circ} 20^{\prime} 3.264^{\prime \prime W}\right)$, and the cyanobacterium was first isolated using soilidified filtered $(0.22 \mu \mathrm{m})$ source water and micromanipulation of filaments. Single filaments were transferred into tubes containing sterile source water and sediment. To successfully culture this cyanobacterium, BG11 marine (35 g. $1^{-1}$ Instant Ocean) was modified by doubling the $\mathrm{CaCl}_{2}, \mathrm{MgSO}_{4}$, and $\mathrm{NaCO}_{3}$ concentrations, adding $\mathrm{NaSiO}_{3}\left(30\right.$ g. $\left.1^{-1}\right), \mathrm{pH}$ adjusted to $9(0.1 \mathrm{M} \mathrm{NaOH}$ dropwise), and adding sterile organic sand. The cyanobacterium is maintained in both modified liquid and solid media at 25 ${ }^{\circ} \mathrm{C}$ on a $12: 12-\mathrm{h}$ light:dark cycle under cool white (6500K) fluorescent lighting $\left(100 \mu \mathrm{Es}^{-1} \cdot \mathrm{cm}^{-2}\right)$. Herbarium voucher specimens are deposited in the US National Herbarium of the National Museum of Natural History, Smithsonian Institution (NMNH-SI, Washington, DC, USA) under the accession number \# US 227647. Live cultures are maintained in the BLCC (Berthold-Laughinghouse Culture Collection; Ft. Lauderdale Research and Education Center, University of Florida, Institute of Food and Agricultural Sciences, Davie, Florida, USA) with strain ID\# BLCC-M67.

Morphological, molecular, and phylogenetic analyses. Microphotographs were taken using a DIC microscope (Leica DM5500 B with LAS V4.12; Leica Microsystems, Switzerland) and an Epifluorescent microscope (Amscope, XYL-606). Fluorescent microscopy was used to image strain characteristics overlooked in light microscopy by using either inherent cyanobacterial autofluorescence or DAPI (4',6-Diamidino-2-Phenylindole, Dihydrochloride) staining for visualization of bacteria.

For molecular analyses, DNA was extracted from 10 $\mathrm{mg}$ of fresh unicyanobacterial material using a Plant Mini Kit (Qiagen) with modified protocols. To maximize extraction efficiency, the biomass was first washed three times with $\mathrm{diH}_{2} \mathrm{O}$ then macerated with a sterile pestle. The $16 \mathrm{~S}$ rRNA gene and 16S-23S rRNA ITS region were amplified by PCR (polymerase chain reaction) on a ProFlex (Applied Biosystems) thermocycler using the primers $359 \mathrm{~F}$ and $1487 \mathrm{R}$ for the $16 \mathrm{~S}$ rRNA gene and $1337 \mathrm{~F}$ and $23 \mathrm{~S} 30 \mathrm{R}$ for the $16 \mathrm{~S}-23 \mathrm{~S}$ rRNA ITS region (WILMOTTE et al. 1993; NüBEL et al. 1997), using a $50 \mu \mathrm{l} \mathrm{PCR}$ reaction of $5 \mu \mathrm{l}$ buffer, $5 \mu \mathrm{l}$ BSA (bovine serum albumin), $2.5 \mu 1 \mathrm{MgCl}_{2}, 1.25 \mu 1$ each primer, $1 \mu 1 \mathrm{dNTPs}, 0.3$ $\mu 1$ GoTaq G2 (Promega), and remainder nuclease-free $\mathrm{H}_{2} \mathrm{O}$. The following conditions were used for amplification: an initial denaturation for $3 \min 95.5^{\circ} \mathrm{C}$, then 35 cycles of denaturation for $30 \mathrm{sec}$ at $95^{\circ} \mathrm{C}$, annealing for $1 \mathrm{~min}$ at $57^{\circ} \mathrm{C}$, extension for $1.20 \mathrm{~min}$ at $72{ }^{\circ} \mathrm{C}$, with a final extension for $5 \mathrm{~min}$ at $72{ }^{\circ} \mathrm{C}$.

A QIAquick PCR Purification Kit was used to clean PCR products which were subsequently visualized on a $1 \%$ agarose gel. The amplified products of the 16S rRNA gene were sequenced directly; however, the 16S-23S rRNA ITS products were cloned using TOP 10 chemically competent cells (TOPO-TA, Invitrogen) prior to sequencing, following manufacture protocols. Cloned plasmids were extracted from clonal libraries using a PureLink Quick Plasmid Miniprep Kit (Invitrogen). Sanger sequencing of plasmid DNA was carried out by Eurofins Genomics (Kentucky, USA) using
BigDye Terminator v3.1 (Applied Biosystems). Sequences for both the 16S rRNA gene and 16S-23S rRNA ITS are deposited in GenBank (National Center for Biotechnology Information, NCBI) under the accession numbers MT321576 and MT321577, respectively.

BLAST (Basic Local Alignment Search Tool, NCBI) was used to identify $16 \mathrm{~S}$ rRNA gene sequences similar to our isolate. A total of 42 sequences were aligned with our isolate using MUSCLE (SeaView v4.4) (EdgAr 2004). The alignment of the 16S rRNA gene included 1349 sites and Gloeobacter violaceus (AY485484) as the outgroup. The best-fit nucleotide model was assessed using jModelTest through MEGA(v10.1.7) (Guindon \& Gascuel 2003; Posada 2008; TAMura et al. 2011). Phylogenetic trees were constructed using Bayesian inferencing (BI) and maximum likelihood (ML) with MrBayes (v3.3.6) and RaxML (7.2.7), respectively, through the CIPRES network (v.3.3) (Guindon \& Gascuel 2003; Miller et al. 2010). The ML analysis was carried out using the GTR + I model using 1,000 bootstrap resampling replicates. The BI analysis was conducted using MrBayes 3.6 (Ronquist \& HuElSENBECK 2003 ) with $1.5 \times 10^{6}$ generations, a 0.25 burn-in rate, and resampling every 100 generations.

\section{Results AND Discussion}

\section{Species Description \\ Johannesbaptistia floridana D.E. Berthold et Laughinghouse sp. nov.}

(Figs 1-3, Suppl. Fig. S1)

Diagnosis: Cells of pseudofilaments are much larger than previous species including Johannesbaptistia pellucida, $J$. primaria, and $J$. willei.

Description: Thallus light to dark blue green, coiled, epipelic on sand/mud, embedded in clear gelatinous matrix, pseudofilaments $\pm 1 \mathrm{~mm}$ long, curved and wavy, 24.0-29.2 (30) $\mu \mathrm{m}$ diam. Unicellular pseudofilaments, mostly uniseriate, sometimes pseudopolyseriate, often pseudodichotomously divaricated. Sheath hyaline, gelatinous, $2.6 \mu \mathrm{m}$ thick, bacterial film often embedded. Healthy, dividing cells and divaricating pseudofilaments contain little to no space between cells. Slight or clear distance between cells in older pseudofilaments. Cell content light to dark green to blue-green, very finely granular, homogeneous, without gas vesicles. Cells discoid, 4.0-7.8 (8.8) $\mu \mathrm{m}$ long and 18.5-23.3 (23.7) $\mu \mathrm{m}$ in width. Apical cell rounded, light green to yellow. Reproduction through filament disintegration, necridia. Forms club-shaped, expansion of cells (8-12 cells) that are twice wider than vegetative cells.

Holotype: US 227647 (US National Herbarium, Smithsonian Institution, Washington, DC, USA) - metabolically inactive herbarium preparation [dried and preserved] of reference strain BLCC-M67. Collected by David E. Berthold on 25-August-2018.

Type locality: Marine sediment in Biscayne Bay, Homestead, Florida, USA $\left(25^{\circ} 27^{\prime} 53.9^{\prime \prime} \mathrm{N}, 80^{\circ} 20^{\prime} 05.8^{\prime \prime} \mathrm{W}\right)$.

Habit and habitat: Benthic and epipelic on marine 


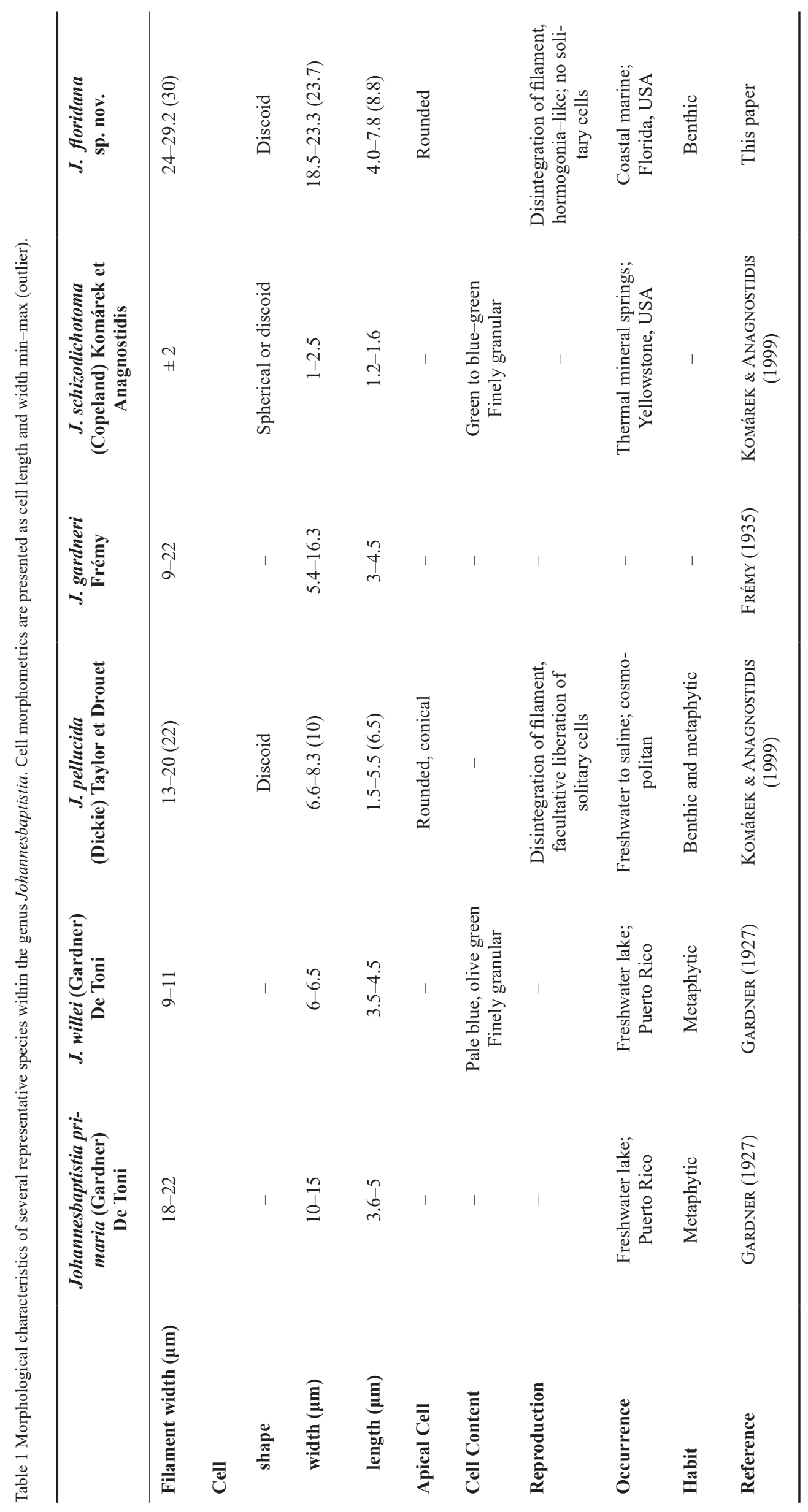




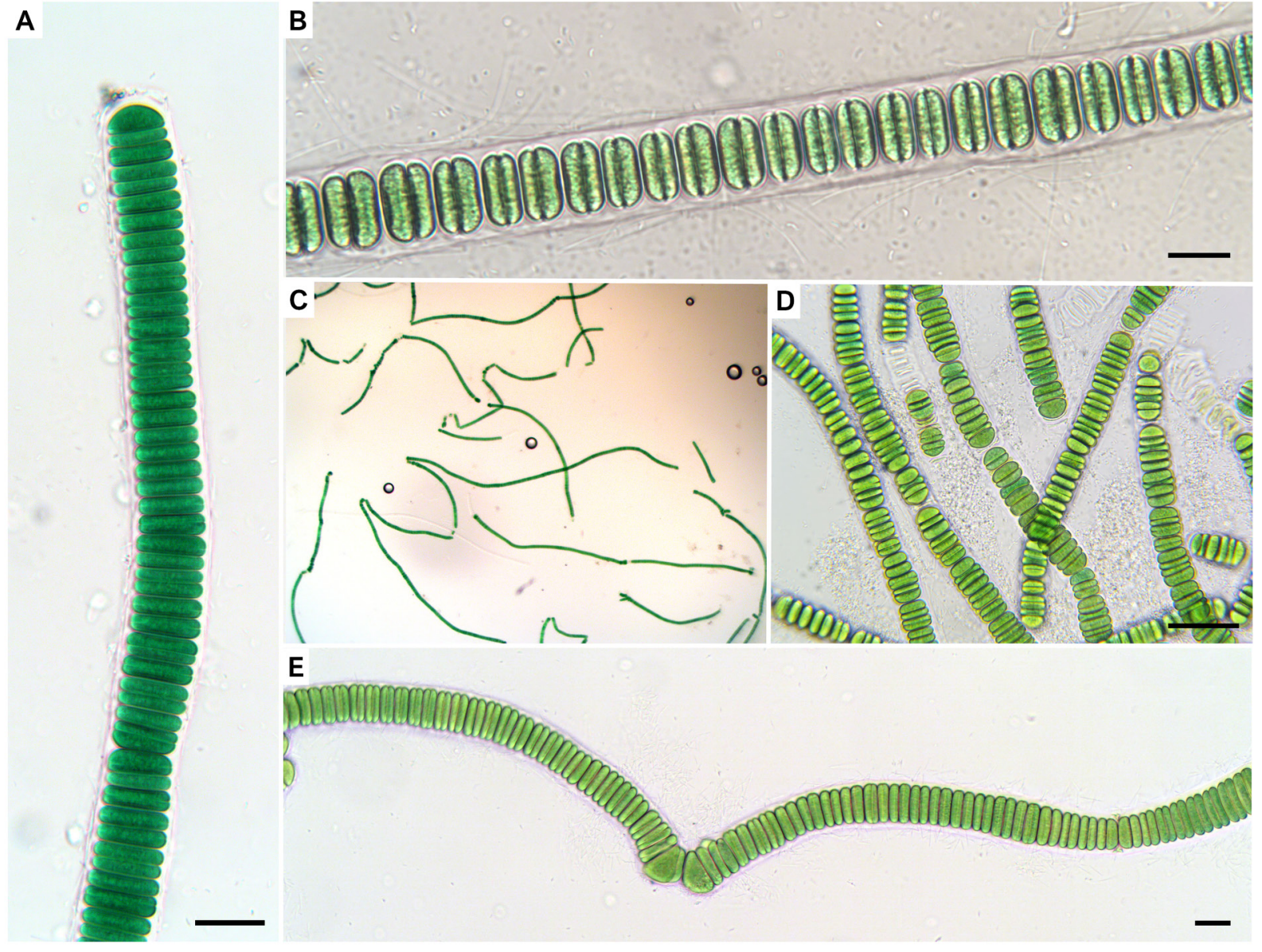

Fig. 1. Microscopic images of Johannesbaptistia floridana sp. nov. (strain BLCC-M67 [reference strain]) showing characteristic morphological traits including: (A) blue-green uniseriate pseudofilament; (B) clear spaces between dividing daughter cells; (C) extensive length of divaricated pseudofilaments; (D) disintegration and necridia of pseudofilaments, and (E) pseudodichotomous divarication of pseudofilaments. Scale bars $20 \mu \mathrm{m}$.

intertidal substrata.

Etymology: "floridana" is to honor the State of Florida (USA) where the cyanobacterium was collected.

Reference strain: BLCC-M67 (University of Florida/ IFAS, FLREC, Davie, FL, USA) and ULC590 (BCCM/ ULC Cyanobactera Collection, University of Liège, Liège, Belgium).

Gene Sequences: GenBank accession numbers MT321576 for the 16S rRNA gene and MT321577 for the 16S-23S rRNA ITS.

\section{Morphological analyses}

Johannesbaptistia floridana sp. nov. demonstrated characteristic morphological features of the genus Johannesbaptistia including blue-green uniseriate pseudofilaments, clear spaces between dividing cells, pseudodichotomously divaricated pseudofilaments and cell division transversely to the longer axis of cells (Figs $1 \mathrm{~A}-\mathrm{C}, \mathrm{E})$. Other typical morphological traits included necridia (Figs 1D, Fig. 2B) of cells within pseudofilaments, cellular anastomization (Fig. 2F), and fine cellular granulation (Fig. 2G).

Besides traditional morphological traits common to Johannesbaptistia, J. floridana has atypical characters not yet described in currently described species. The apical cell of $J$. floridana consistently appears light yellow in comparison to the deeper blue-green of nearby vegetative cells (Fig. 2C). Other observations made throughout the life cycle of J. floridana include a club-shaped cellular deformity where cells can become twice as wide (Fig. 3C). Teratogenic forms in cultures have previously been observed in Johannesbaptistia, where culture conditions shift from unfavorable to favorable (RichERT et al. 2006).

Johannesbaptistia floridana sp. nov. has an extensive network of relatively large filamentous heterotrophic bacteria that form a texturized mat over the surface of the cyanobacterium sheath (Fig. 3A, B). This bacterial layer is further accentuated along with morphological oddities of $J$. floridana using fluorescent microscopy (Suppl. Fig. 1A). This bacterial layer is a feature that may or may not be artificial from culturing. DAPI and natural fluorescence of cells show cellular divarication at cell to cell junctions and following cell necrosis. Furthermore, a combination of autofluorescence and DAPI stained cyanobacteria show cellular division in one plane (Suppl. Figs 1B-E).

Johannesbaptistia floridana sp. nov. and J. pellucida share some similarities in morphological traits (Table 1). 


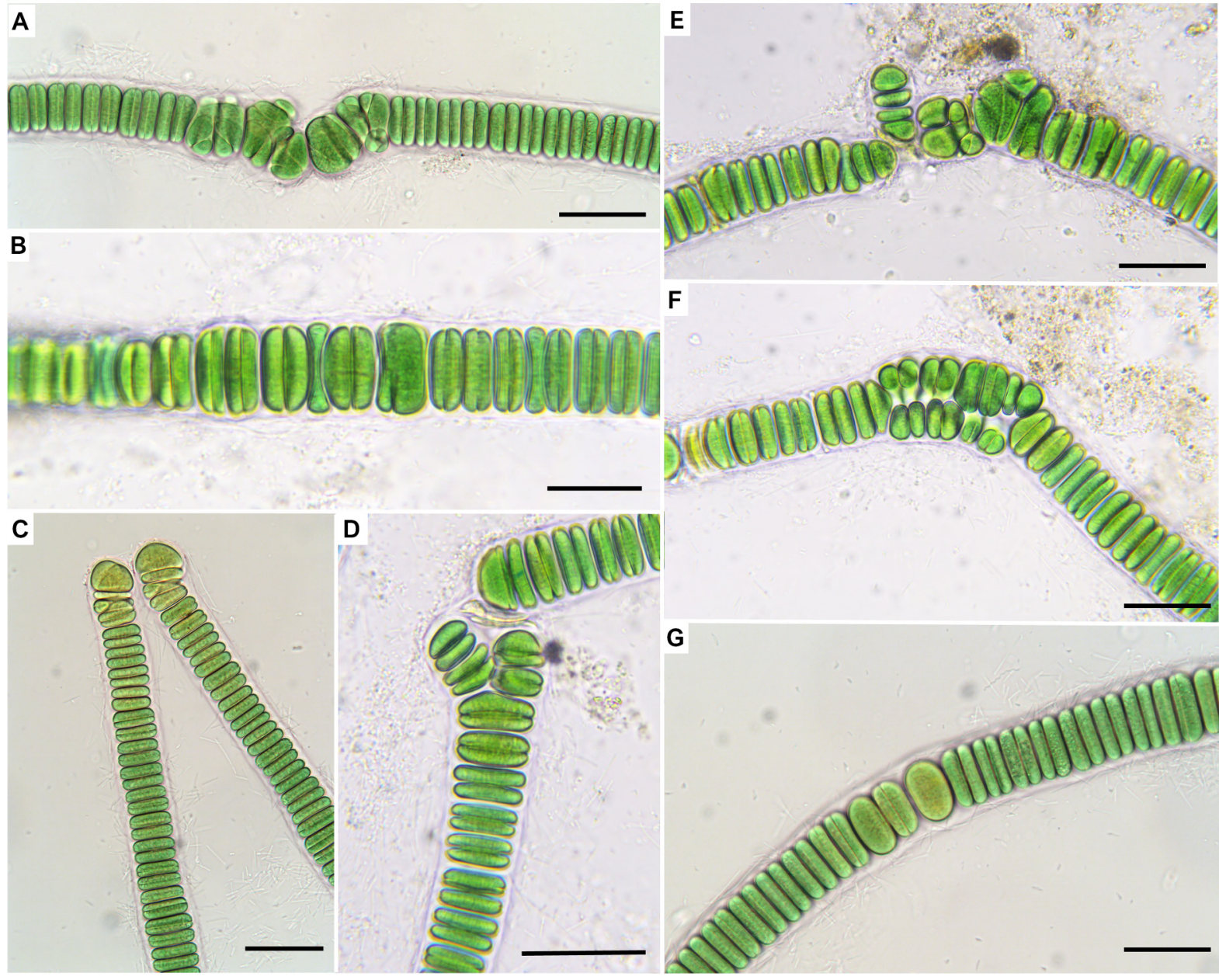

Fig. 2. Microscopic images of Johannesbaptistia floridana sp. nov. (strain BLCC-M67 [reference strain]) showing non-traditional morphological traits of this genus including: (A) cell division in single plane within apical cells; (B) necridia of pseudofilaments; (C) characteristic yellowing of apical cells; (D) pseudobranching at the apical cell junction; (E) cell division; (F) anastomization of cells, and G) fine cell granulation with large yellow dividing cell before divarication. Scale bars $50 \mu \mathrm{m}$.

These two species contain similar cell shape and content with discoid cells and fine granulation, and pseudofilaments that are capable of reproduction by disintegration. The two species differ in terms of reproduction, where $J$. pellucida facultatively releases single cells, a characteristic not observed in J. floridana. The most noticeable difference between $J$. floridana and all other described species of Johannesbaptistia is the pseudofilament and cell dimensions. Johannesbaptistia floridana is larger than all other currently described species of this genus, with cells of 24.0-29.2 (30.0) $\mu \mathrm{m}$ (Table 1).

\section{Molecular and phylogenetic analyses}

Molecular data for representatives of the genus Johannesbaptistia are currently scarce, with only one partial 16S rRNA gene sequence deposited in GenBank of $J$. pellucida kopara-GC (RICHERT et al. 2006). Johannesbaptistia floridana sp. nov. forms a well-supported clade (BI: 1.0; ML: 100) with J. pellucida kopara-GC (Fig. 4). Our data also show that the genus Johannesbaptistia is sister to the genus Limnococcus (BI: 1.0; ML: 100), and more distantly related to Gomphosphaeria (BI: 0.97; ML:
-). Pairwise distance (data not shown) for $J$. pellucida kopara-GC and J. floridana is $98.0 \%$.

The 16S-23S rRNA ITS secondary structure of $J$. floridana is presented in Figure 5. Since molecular data for Johannesbaptistia is limited, we present the secondary structures of closely related strains for comparison. Compared to closely related taxa with available molecular data, including Crocosphaera, Inacoccus, Pleurocapsa, and Synechocystis, the D1-D1' region of J. floridana is different in structure; the D1-D1' is extensive with 93 nucleotides similar to that of Crocosphaera with 92 nucleotides, while the remaining taxa contain only 64 nucleotides. Alternatively, while disparate from that of Crocosphaera, Pleurocapsa, and Synechocystis, the Box B region of J. floridana is identical to that of Inacoccus with a total of 33 nucleotides.

The new taxon Johannesbaptistia floridana proposed in this study is based on criteria including monophyly and a combination of molecular and morphological traits previously outlined by JOHANSEN \& CASAMATTA (2005). The 16S rRNA of $J$. floridana has enough dissimilarity (p-distance) to J. pellucida, to separate the two species 


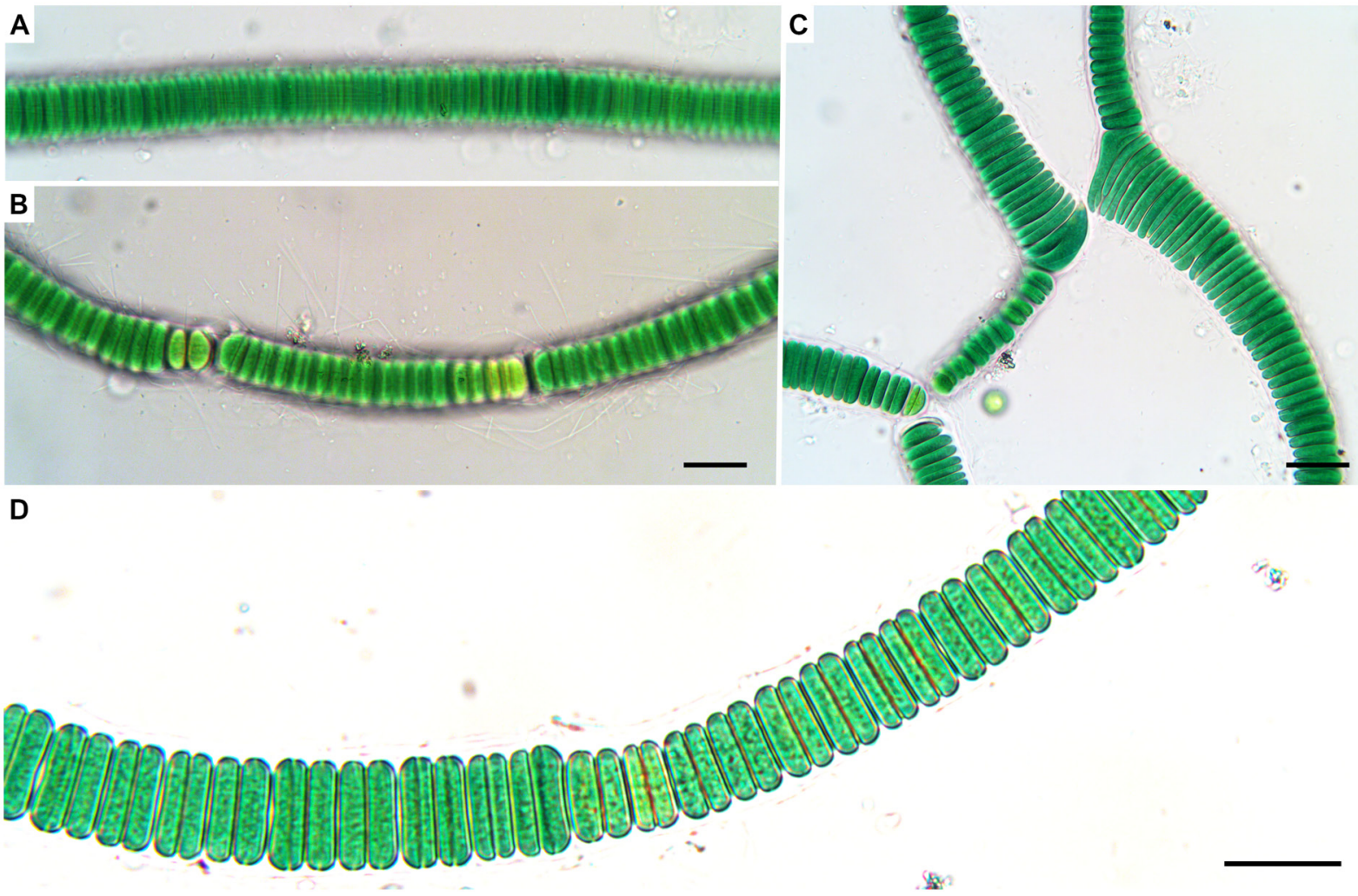

Fig. 3. Microscopic images of Johannesbaptistia floridana sp. nov. (strain BLCC-M67 [reference strain]) showing remarkable characteristics including: (A) texturized appearance of gelatinous sheath; (B) extent of bacterial biofilms covering sheath; (C) club-shaped cell teratology, and D) cell size variation within a pseudofilament. Scale bars $30 \mu \mathrm{m}$.

based on the $<98.7 \%$ suggested cutoff (YARZA et al. 2014). The $16 \mathrm{~S}$ rRNA gene phylogeny shows high support for J. floridana as a novel species. Morphological traits of $J$. floridana include contrasting cellular dimensions. The combination of $16 \mathrm{~S}$ rRNA gene phylogeny and sequence similarity support, along with the diagnosable morphological characteristics supports the erection of the novel species $J$. floridana.

\section{ACKNOWLEDGEMENTS}

This work was partly supported by the USDA National Institute of Food and Agriculture, Hatch project \# FLA-FTL-005697, University of Florida/IFAS Early Career Seed Grant, and by the Florida Sea Grant College Program of the U.S. Department of Commerce's National Oceanic and Atmospheric Administration (NOAA), Grant No. NA 18OAR4170085. The views expressed are those of the authors and do not necessarily reflect the views of these organizations.

\section{REFERENCES}

Copeland, J.J. (1936): Yellowstone thermal Myxophyceae. - Ann. New York Acad. Sci. 36: 1-232.

DiCKIE, G. (1874): Enumeration of algae from Fernando de Noronha, collected by H.N. Moseley, M.A., naturalist to H.M.S. "Challenger". - J. Proc. Linn. Soc. Bot. 14: 363-365.

De Toni, G. (1934): Noterelle di nomenclatura algologica. I. Alcuni casi di omonimia (Missoficee). - Tipografia Morcelliana Brescia 13: 1-7

Droute, F. (1938): Notes on Myxophyceae. I-IV. - Bulletin of the Torrey Botanical Club 65: 285-292.
EDGAR, R.C. (2004): MUSCLE: multiple sequence alignment with high accuracy and high throughput. - Nucleic Acids Res 32: 1792-1797.

FrÉMY, P. (1935): Trois Cyanophycées nouvelles de l'Afrique de Nord. - Bull. Soc. Hist. Nat. Afrique N. 26: 89-101.

Gardner, L.N. (1927): New Myxophyceae from Puerto Rico. Mem. New York Bot. Gard 7: 1-144.

Golubić, S. \& ABED, R.M.M. (2010): Entophysalis mats as environmental regulators. - In: SECKBACH, J. \& OREN, A. (eds.): Microbial Mats: Modern and Ancient Microorganisms in Stratified Systems, Cellular Origin, Life in Extreme Habitats and Astrobiology, vol. 14. - pp. 237-251, Springer, Dorrecht.

Guindon, S. \& GASCuEL, O. (2003): A simple, fast, and accurate algorithm to estimate large phylogenies by maximum likelihood. - Syst. Biol. 52: 696-704.

GuirY, M.D. \& GuirY, G.M. (2020): AlgaeBase. World-wide electronic publication, National University of Ireland, Galway. http://www.algaebase.org

HINDÁK, F. (1988): Contribution to the taxonomy of some cyanophyte genera. - Preslia 60: 289-308.

Johansen, J.R. \& CASAMATta, D.A. (2005): Recognizing cyanobacterial diversity through adoption of a new species paradigm. - Algol. Studies 117: 71-93.

KoMÁREK, J. \& ANAGNOSTIDIS, K. (1986): Modern approach to the classification system of cyanophytes. 2- Chroococcales. Arch. Hydrobiol. Suppl. 73.2, Algol. Studies 43: 157-226.

KomáreK, J. \& ANAGNostidis, K. (1999): Cyanoprokaryota. I. Chroococcales. - In: EtTL, H.; GÄrTNER, G.; HeYNIG, H. \& Mollenhauer, D. (eds.): Süßwasserflora von Mitteleuropa, Band 19/3. - 548 pp., Spektrum Akademischer Verlag, Heidelberg \& Berlin.

KomÁreK, J. \& KomÁrková-Legnerová, J. (2007): Taxonomic 


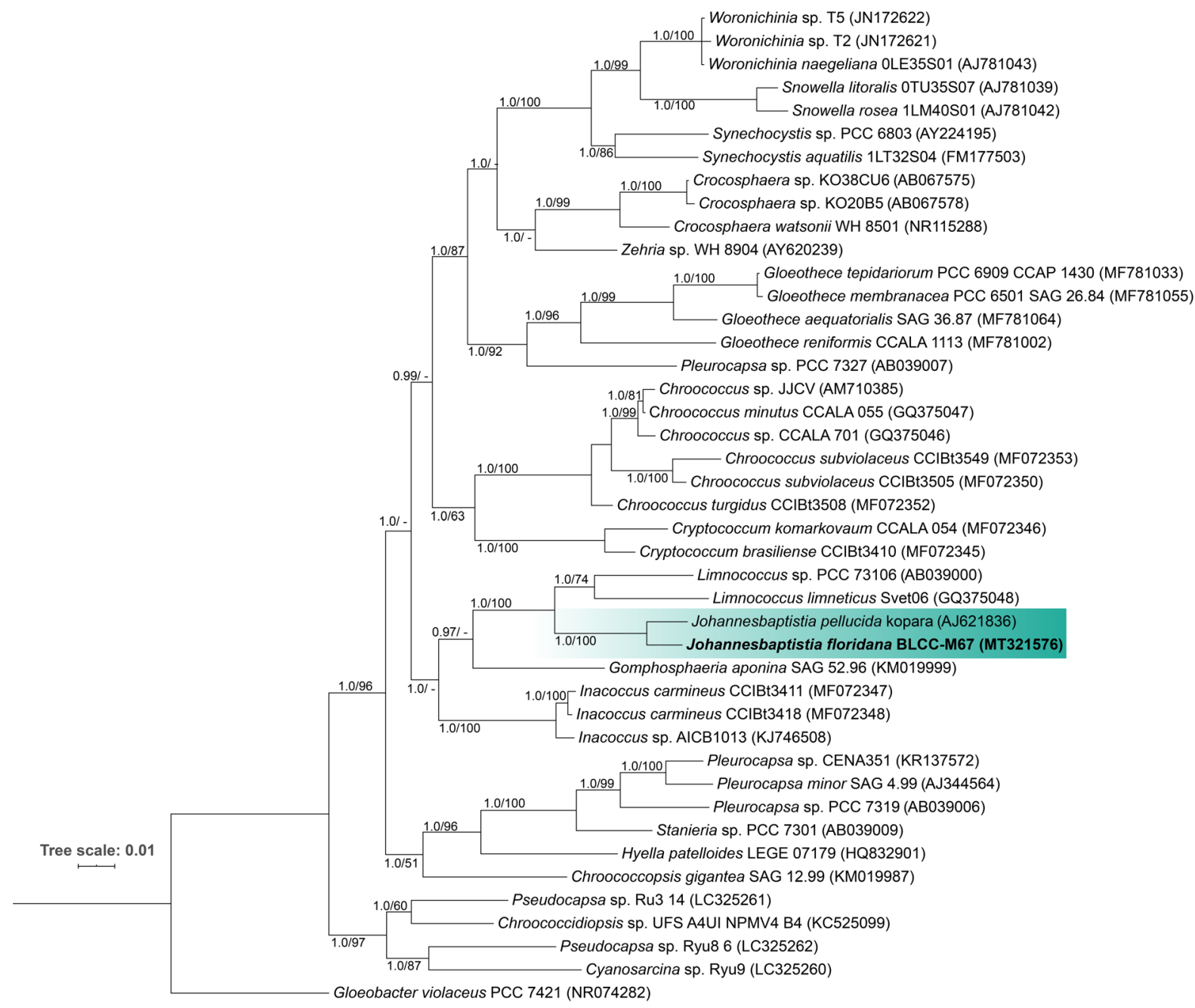

Fig. 4. Maximum likelihood and Bayesian inference (16S rRNA) of the phylogenetic relationship of Johannesbaptistia floridana sp. nov. (strain BLCC-M67) and 41 taxa of Chroococcales plus Gloeobacter violaceous PCC 7421(NR074282) as the outgroup. Posterior probabilities (PB) and bootstrap support (BS) are indicated at the nodes. A - indicates less than 0.50 (PB) or 50\% (BS) support.

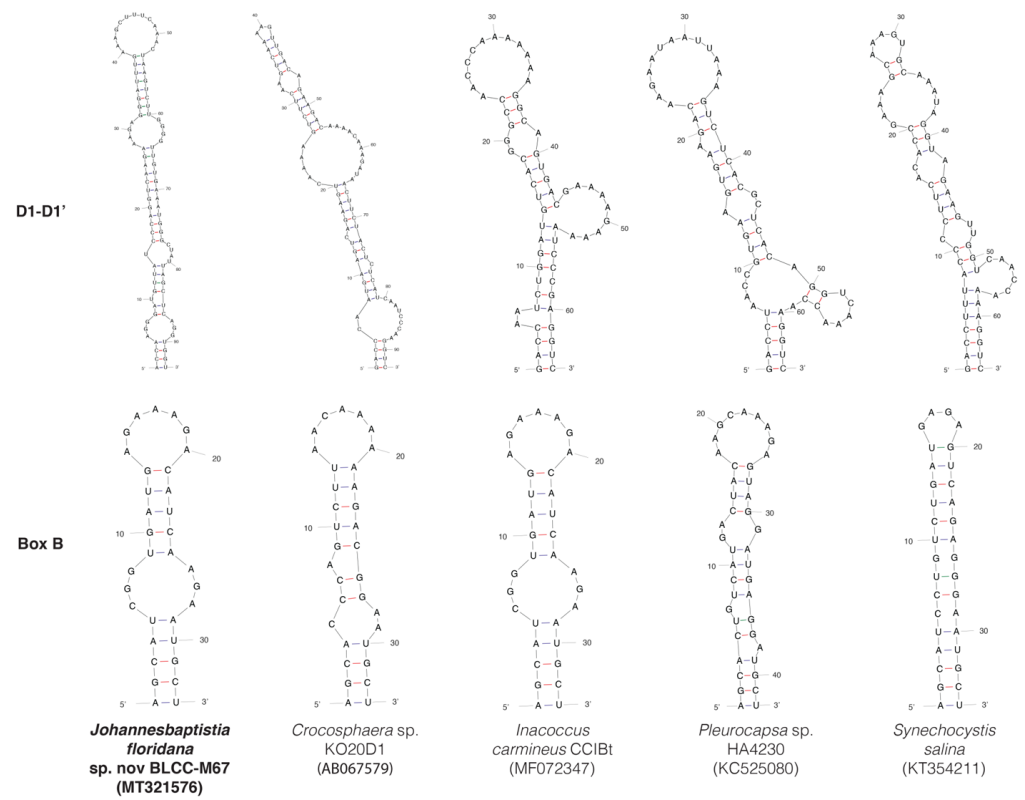

Fig. 5. Secondary structures of the 16S-23S rRNA internal transcribed spacer (ITS) of Johannesbaptistia floridana BLCC-M67 and other taxa of the Order Chroococcales. 
evaluation of cyanobacterial microflora from alkaline marshes of northern Belize. 1. Phenotypic diversity of coccoid morphotypes. - Nova Hedwigia 84: 65-111

Marshall, G.H. (1981): Occurrence of bluegreen algae (Cyanophyta) in the phytoplankton off the southeastern coast of the United States. - J. Plankton Res. 3: 163-166

Miller, M.A.; Pfeiffer, W. \& Schwartz, T. (2010): “Creating the CIPRES Science Gateway for inference of large phylogenetic trees" in Proceedings of the Gateway Computing Environments Workshop (GCE), 14 Nov. 2010. - pp. 1-8, New Orleans, LA.

NÜBel, U.; Garcia-Pichel, F. \& MuYzer, G. (1997): PCR primers to amplify $16 \mathrm{~S}$ rRNA genes from cyanobacteria. - Appl. Environ. Microbiol. 63: 3327-3332.

Richert, L.; Golubič, S.; GuÉdès, R.L.; Hervé, A. \& PAYri, C. (2006): Cyanobacterial populations that build 'kopara' microbial mats in Rangiroa, Tuamotu Archipelago, French Polynesia. - Eur. J. Phycol. 41: 259-279.

Ronquist, F. \& HuELSENBECK, J.P. (2003): MrBayes 3: Bayesian phylogenetic inference under mixed models. - Bioinformatics 19: $1572-1574$

Rosen, B.H. \& MAREš, J. (2016): Catalog of microscopic organisms of the Everglades, Part 1: The cyanobacteria. U.S. Geological Survey Open-File Report 2016-1114. - 108 pp., U.S. Geological Survey, Reston, VA.

SchmidLe, W. (1897): Zur Entwickelung einer Zygnema und Calothrix. - Flora, Bd. 84, Heft 2

TAYLOR, W.R. (1928): The marine algae of Florida with special reference to the Dry Tortugas. - Pap. Tortugas Lab. Carnegie Inst. Wash. 25: 1-219.

WenZEL, M.T. \& HALPERIN, D.R. (1987): Johannesbaptistia pellucida (Cyanophyta, Entophysalidaceae): genero y especie nuevos para Argentina. - Darwiniana 28: 303-306

Wilmotte, A., VAn der Auwera, G. \& De Wachter, R. (1993): Structure of the $16 \mathrm{~S}$ ribosomal RNA of the thermophilic cyanobacterium Chlorogloeopsis HTF ('Mastigocladus laminosus HTF') strain PCC7518, and phylogenetic analysis. - FEBS Letters 317: 96-100.

Yarza, P.; Yilmaz, P.; Pruesse, E.; GlöcKner, F. O.; Ludwig, W.; SChleifer, K.; Whitman, W. B.; EuzÉby, J.; AmanN, R. \& Rosselló-Móra, R. (2014): Uniting the classification of cultured and uncultured bacteria and archaea using 16S rRNA gene sequences. - Nature Rev. Microbiol. 12: 635-645.

Supplementary material

The following supplementary material is available for this article:

Fig. S1. Fluorescent microphotographs of Johannesbaptistia floridana sp. nov.

This material is available as part of the online article (http:// fottea.czechphycology.cz/contents)

(C) Czech Phycological Society (2020)

Received April 11, 2020

Accepted May 6, 2020 